\title{
Production of Inhibitory Compounds against Helicobacter pylori by Culture Condition of Morus alba cv. Cheongmoknosang Callus
}

\author{
Young-Je Cho ${ }^{1}$, Won-Seup Cha', Sun-Ae Kang ${ }^{2}$, Bong-Jeun $\mathrm{An}^{3}$, Dong-Hyun $\mathrm{Ahn}^{4}$, Myung-Uk Kim \\ and Jung-Woo Chae ${ }^{6}$
}

\author{
${ }^{1}$ School of Food science \& Biotechndogy / Food \& Bio-Industry Research Institute, Kyungpook National University, Daegu 702-701, Korea \\ ${ }^{2}$ School of Applied Bioscience, Kyungpook National University, Daegu 702-701, Korea \\ ${ }^{3}$ Department of Cosmeceutical Science, Daegu Hanny University, Gyeongsan 712-715, Korea \\ ${ }^{4}$ Department of Food Science \& Technology, Institute of Food Science, Pukyong National University, Busan 608-737, Korea \\ ${ }^{5}$ Gyungbuk Institute for Marine Bio-Industry, Uljin 767-813, Korea \\ ${ }^{6}$ Gyeonggi-do Forest Environment Research Institute, Osan 447-290, Korea
}

Received August 9, 2012 /Revised January 23, 2013 / Accepted February 11, 2013

\begin{abstract}
The optimal condition for Morus alba cv was an MS culture medium at $27^{\circ} \mathrm{C}$ for 20 days. Cheongmoknosang callus showed inhibitory activity against Helicobacter pylori at $1.05 \mathrm{~g}$ of wet weight of the cultured callus. The callus formation of Morus alba cv. Cheongmoknosang was influenced by naphthalene acetic acid (NAA), 2,4-dichlorophenoxy acetic acid (2,4-D), 6-benzylaminopurine (BA) and kinetin at concentrations of $2 \mathrm{mg} / \mathrm{l}$. The growth rate of callus was higher than it was when these hormones were mixed with a single hormone. Thus, the optimal condition for direct callogenesis was to incubate with mixture (2,4-D/NAA) of $2 \mathrm{mg} / \mathrm{l}$ concentration at $27{ }^{\circ} \mathrm{C}$ for 20 days. Moreover, the optimal culture condition of the biomass in the mass production of inhibitory compounds against Helicobacter pylori from Morus alba cv. Cheongmoknosang callus was to incubate in an MS broth (each concentration $1 \mathrm{mg} / \mathrm{l}$ of 2,4-D and BA). When Morus alba cv. Cheongmoknosang callus were incubated for 20 days in a bioreactor, Helicobacter pylori inhibition of callus extracts was the highest at a clear zone of $16 \mathrm{~mm}$.
\end{abstract}

Key words : Callus, Morus alba cv. Cheongmoknosang, culture condition, inhibitory activity, Helicobacter pylori

\section{서 론}

뽕나무(Morus alba)는 전국에 재식하며 일본, 만주, 중국, 몽 골 등 동아시아에 널리 분포한다. 잎은 상엽이라고 하며, 거풍, 청열, 명목의 효능이 있고, 발열, 두통, 목적, 구갈을 치료하는 데 예로부터 이용되어 오고 있는 것으로 전해진다[11]. 또한 뽕나무는 풍으로 인한 소양증과 건조, 각기 풍기, 사지 경련, 숨이 막히는 증상을 치료하고 음식을 소화하며, 소변이 잘 나 오게 하는 약리효과를 가지고 있다[3]. 그리고 뽕나무 잎에는 flavones, steroids, triterpenes, amino acids, vitamin 및 다량 의 미네랄 성분이 존재하고 있으며, 또한 전통 생약으로 당뇨 병을 예방, 치료하며 갈증을 해소시키는 것으로 알려져 있다 [5]. Asano는 뽕나무 잎으로부터 N-containing sugars를 분리, 동정 하였으며 $[2,4,14]$ 뽕잎의 혈당강하효과에 대한 영향을

\section{*Corresponding author}

Tel : +82-53-950-7755, Fax : +82-53-950-7762

E-mail : yjcho@knu.ac.kr

This is an Open-Access article distributed under the terms of the Creative Commons Attribution Non-Commercial License (http://creativecommons.org/licenses/by-nc/3.0) which permits unrestricted non-commercial use, distribution, and reproduction in any medium, provided the original work is properly cited.
발표하였다. 그 와 더불어 뽕나무 껍질은 예로부터 우리나라 에서 상백피라는 약재로써 고혈압 치료 등에 쓰여 왔다[1, 19]. 본 연구팀은 현재 국내에 보존되어오고 있는 뽕잎 108종의 기능성 및 Helicobacter pylori 억제력을 검토한 바 있고[8], 그 중 청목노상 품종의 뽕잎에서 항산화 및 항염증 작용이 우수 한 것으로 보고하였다[7,9].

식물은 식량자원으로의 역할 이외에도 기내에 함유된 유용 물질을 직접 추출하여 얻으나, 외부 인자에 의한 영향에 의해 안정된 공급이 힘들고, 유용물질의 함량이 낮고 생장 속도가 느려 대량생산하기가 어렵다[3]. 식물세포배양공학을 이용한 유용물질 생산기술은 생명과학분야에서 식물자원생산 이용 기술로서 식물생물공학 분야의 근간을 형성하고 있다. 이 기 술은 식물유래 유용물질의 생산을 안정적으로 대량 생산할 수 있는 것을 특징으로 하며, 세포배양기술, 생리효과 연구, 분리정제기술, 대량배양기술 등으로 이루어져 있다 $[6,12,15]$. 윤 등[20]은 청목노상 뽕잎 callus에서도 Helicobacter pylori에 대한 억제물질이 생산되며, 항균효과가 뛰어나다고 보고한 바 있다.

따라서 본 연구에서는 생리활성이 우수한 청목노상 뽕잎의 기능성 물질의 대량생산 방안을 위한 연구의 일환으로 청목노 
상 세포배양을 이용하여 Helicobacter pylori 억제물질의 대량생 산을 위한 연구의 일환으로 Helicobacter pylori에 대한 억제 효 과를 가지는 청목노상 뽕잎 callus의 biomass를 위한 배양최적 조건을 규명하여, Helicobacter pylori 억제에 기인하는 기능성 물질의 대량 생산 가능성을 연구하고자 하였다.

\section{재료 및 방법}

재료

실험재료인 청목노상 뽕잎은 경상북도 상주시 잠사시험장 에서 5 월에 수집한 어린잎을 세척한 후 물기를 제거하고 $4^{\circ} \mathrm{C}$ 냉장고에 보관하면서 사용하였다.

\section{Spot 접종, 배양 및 callus 유도}

Spot 접종은 채취한 청목노상 잎 시료를 24 시간 이내에 $70 \%$ 에탄올을 사용하여 10초간 3회 표면 살균 후 $1 \%$ sodium hypochlorite로 20분간 살균하고, 멸균수로 수회 세척하여 가 로x세로 약 $1 \mathrm{~cm}$ 정도의 크기로 잘라 내어 고체배지에 spot 접종하였다. 이때 사용된 고체 배지는 $\mathrm{MS}$ 배지를 사용하였으 며[19], $27^{\circ} \mathrm{C}$ 암소에서 30 일간 평판 배양하였다. Callus의 유도
는 MS배지에 탄소원으로 saccharose를 $30 \mathrm{~g} / 1$ 의 농도로 처리 하였으며, 생장조절제로서 naphthalene acetic acid (NAA), 2,4-dichlorophenoxy acetic acid (2,4-D), 6-benzylaminopurin (BA)와 kinetin 같은 plant growth regulator를 $10 \mu \mathrm{M}$ 의 농도 로 처리된 배지에 시료를 치상하고 $27^{\circ} \mathrm{C}$ 에서 암배양 하였다. Callus 형성배지에서 형성된 callus는 4 주 간격으로 계대 배양 하였다.

\section{청목노상 뽕잎 callus 배양}

청목노상 뽕잎 callus의 생육을 위한 배양 조건을 찾기 위해 다양한 생장조절제의 농도와 종류를 제시하였으며, 생장조절 제의 경우 $1 \sim 3 \mathrm{mg} / 1$ 의 농도로 처리하였고, 종류와 조합방법은 Table 1, 2와 같이 실시하였다.

Biomass를 위한 callus starter 제조 및 bioreactor 배양

Spot접종하여 배양된 배지의 callus를 잘게 자른 후, 자른 조각을 $100 \mathrm{ml}$ 의 멸균된 액체 배지에 접종하여 증식시키고, 다시 $500 \mathrm{ml}$ 의 액체 배지에 접종하여 배양시켜 starter를 제조 하고, starter 전량을 $2.4 \mathrm{D}$ 와 $\mathrm{BA}$ 를 각각 $1 \mathrm{mg} / 1$ 의 농도로 첨가 한 101 의 bioreactor에 접종하였다. 접종된 bioreactor는 $27^{\circ} \mathrm{C}$

Table 1. Effect of plant growth regulator concentration on callus formation from Morus alba cv. Cheongmoknosang mulberry leaves

\begin{tabular}{lcc}
\hline Plant growth regulator & Concentration of plant growth regulator $(\mathrm{mg} / \mathrm{l})$ & Wet weight of cultured callus $(\mathrm{g})$ \\
\hline \multirow{3}{*}{ Naphthalene acetic acid } & 1 & $1.02 \pm 0.14$ \\
& 2 & $1.08 \pm 0.11$ \\
& 3 & $1.08 \pm 0.11$ \\
\hline \multirow{2}{*}{ 2, 4-Dichlorophenoxy acetic acid } & 1 & $1.05 \pm 0.14$ \\
& 2 & $1.13 \pm 0.07^{*}$ \\
& 3 & $1.10 \pm 0.11^{*}$ \\
\hline \multirow{2}{*}{ 6-Benzylaminopurine } & 1 & $1.08 \pm 0.11$ \\
& 2 & $1.05 \pm 0.14$ \\
Kinetin & 3 & $1.03 \pm 0.14$ \\
\hline
\end{tabular}

Incubation at $27^{\circ} \mathrm{C}$ for 20 days.

Each value represents the mean \pm S.D $(n=3, p<0.05)$.

Table 2. Effect of mixed plant growth regulator on callus formation from Morus alba cv. Cheongmoknosang mulberry leaves

\begin{tabular}{lcc}
\hline Mixed plant growth regulator & Concentration of plant growth regulator $(\mathrm{mg} / \mathrm{l})$ & Wet weight of cultured callus $(\mathrm{g})$ \\
\hline 2,4-D+BA+NAA & 2 & $1.31 \pm 0.11$ \\
NAA+BA+Kinetin & 2 & $1.29 \pm 0.11$ \\
NAA+2,4-D+Kinetin & 2 & $1.34 \pm 0.14$ \\
2,4-D+BA & 2 & $1.38 \pm 0.14^{*}$ \\
2,4-D+NAA & 2 & $1.43 \pm 0.14^{*}$ \\
NAA+Kinetin & 2 & $1.26 \pm 0.11$ \\
\hline
\end{tabular}

Incubation at $27^{\circ} \mathrm{C}$ for 20 days.

NAA: Naphthalene acetic acid, 2,4-D: 2,4-Dichlorophenoxy acetic acid, BA: 6-Benzylaminopurine.

Each value represents the mean \pm S.D $(n=3, p<0.05)$. 
암조건에서 30 일 정도 액체배양 시켰으며, 생육정도는 배양이 끝난 후 bioreactor의 공기주입을 멈추어 bioreactor 안에 가라 앉는 callus를 수거하여 생체 중량을 측정하였다.

\section{뽕잎 및 뽛잎 callus 추출물의 조제}

청목노상 뽕잎과 뽕잎 callus 추출물은 뽕잎 분말시료와 최 적조건에서 배양한 후 bioreactor에서 수거한 청목노상 callus 를 수세 및 건조, 분쇄한 후 건조 callus 각 $1 \mathrm{~g}$ 에 $80 \%$ ethanol $100 \mathrm{ml}$ 를 가하고 $4^{\circ} \mathrm{C}$ 에서 24 시간 진탕 추출한 후 상징 액을 Whatman No.1 여과지로 여과하였으며, 필요에 따라 rotary vacuum evaporator에서 농축하여 사용하였다.

\section{HPLC 조건}

청목노상 뽕잎과 생장 조절제로 유도된 callus로부터 제조 된 추출물들을 HPLC를 이용하여 callus 추출물에 함유된 $H$. pylori에 대한 항균활성 물질의 profile을 분석하였다. 즉, 뽕잎 과 callus 추출물을 $0.2 \mu \mathrm{m}$ filter로 여과한 후 여과액 $5 \mu \mathrm{l}$ 를 HPLC에 주입하여 분석하였다. 분석 조건은 Xterra column (Waters, RP-18, 250×4.6 mm)을 $30^{\circ} \mathrm{C}$ 로 유지하였고, 검출기는 Waters $2487 \mathrm{UV}$ detector를 사용하여 $306 \mathrm{~nm}$ 에서 측정하였으 며, 이동상은 acetonitile과 formic acid ( $\mathrm{pH} \mathrm{3.0)이고,} \mathrm{기울기}$ 용리 조건은 5 분 동안 acetonitile $10 \%$ 를 용출시켰고, 그 후 30 분간 농도를 $50 \%$ 로 증가시키고 다시 5 분간 $10 \%$ 로 감소시켜 총 45 분간 용매를 이동시켰다. 이때 용매의 흐름 속도는 0.5 $\mathrm{ml} \not$ min 이었다.

\section{Helicobacter pylori 배양}

실험에 사용한 균주는 위, 십이지장 궤양 원인균인 $H$ pylori 로서 표준균주인 ATCC 43504를 사용하였다. H. pylori의 배양 에는 최적배지(special peptone $0.5 \mathrm{~g}$, agar $0.75 \mathrm{~g}, \mathrm{NaCl} 0.25$ $\mathrm{g}$, yeast extract $0.25 \mathrm{~g}$, beef extract $0.2 \mathrm{~g}$ 및 pyruvic acid 0.025 $\mathrm{g}$ )를 사용하여 험기성 조건을 유지시켜주기 위해서 $10 \% \mathrm{CO}_{2}$ incubator를 이용하였으며, incubator의 습도는 항상 $95 \%$ 이 상으로 유지하였으며, agar plate상에서 배양은 $37^{\circ} \mathrm{C}$ 로 $48 \sim 72$ 시간 동안 실시하였다[8].

\section{뽕잎 및 뽕잎 callus 추출물의 Helicobacter pylori 항균} 활성 검색

$H$ pylori에 대한 추출물들의 항균활성 검색은 disc agar diffusion method로 실시하였다[10]. Disc agar diffusion 법은 $H$. pylori 최적배지 plate에 H. pylori균 $100 \mu 1$ 를 분주하여 멸균 유리봉으로 도말한 다음, 멸균된 disc paper $(\phi 8 \mathrm{~mm})$ 를 올리 고 $0.45 \mu \mathrm{m}$ membrane filter로 제균한 각 추출물을 vacuum evaporator로 농축한 후 멸균수로 희석하여 뽕잎과 뽕잎 callus 추출물속에 phenolic compound 함량이 50 200 $\mathrm{\mu g} / 100$ $\mu \mathrm{l}$ 가 되도록 조절한 후 각 추출물 $100 \mu 1$ 를 disc paper에 흡수
시키고, 대조구로는 멸균수를 흡수시킨 후 $37^{\circ} \mathrm{C}$ 의 미 호기성 조건에서 48 시간 동안 incubation한 다음, disc 주위의 clear zone 생성 유무를 확인하였다.

\section{Phenolic content 정량}

Phenolic content의 정량은 시료 $1 \mathrm{ml}$ 에 $95 \%$ ethanol $1 \mathrm{ml}$ 와 증류수 $5 \mathrm{ml}$ 를 첨가하고 $1 \mathrm{~N}$ Folin-ciocalteu reagent 0.5 $\mathrm{ml}$ 를 넣어 잘 섞어주고, 5 분간 방치한 후, $\mathrm{Na}_{2} \mathrm{CO}_{3} 1 \mathrm{ml}$ 를 가한 후, 흡광도 $725 \mathrm{~nm}$ 에서 1시간 이내에 측정하여 gallic acid를 이용한 표준곡선으로부터 양을 환산하였다.

\section{결과 및 고찰}

청목노상 뽕잎과 callus 추출물에 존재하는 항균 phenolic compounds profile의 비교

뽕잎 속에 존재하는 phenolic compound를 만성 위, 십이지 장 질병과 관련이 있는 것으로 알려진 $H$ pylori에 대한 저해제 로 활용하기 위한 연구의 일환으로, 청목노상 뽕잎 추출물과 청목노상 뽕잎 callus 추출물의 $H$ pylori에 대한 저해양상을 비교한 결과 Fig. 1에서와 같이 청목노상 뽕잎이 나타내는 clear zone $15 \mathrm{~mm}$ 의 H. pylori에 대한 항균력보다 청목노상 뽕잎의 callus 추출물에 의한 항균력이 $18 \mathrm{~mm}$ 의 clear zone으 로 훨씬 우수한 것을 알 수 있었다. 이는 Cho 등[9]이 청목노상 뽕잎추출물에서 H. pylori에 대한 저해제로 caffeic acid, rosmarinic acid 및 chlorogenic acid의 혼합물에 의한 저해양상이 나타난다고 보고한 것과 Yoon 등[20]이 뽕잎에서는 발견되지 않은 물질이지만 청목노상 뽕잎의 callus에 다량으로 존재하는 것으로 밝혀진 protocatecuic acid가 항균역할을 수행하는 것 으로 보고한 것을 미루어 짐작하면 각 추출물속에 존재하는 phenolic compound의 profile에 의하여 H. pylori의 저해 양상 은 달라질 것이라 판단되었다. 본 연구에서 동량의 phenolic content를 함유하는 뽕잎과 뽕잎 callus 추출물의 phenolic compound profile의 HPLC 분석결과 Fig. 2에서와 같이 뽕잎 callus의 경우 $H$ pylori 억제 양상에 중요한 역할을 수행하는 것으로 보고된[20] caffeic acid의 함량은 뽕잎과 뽕잎 callus의 두 추출물에서 비슷하게 측정되었으나, 뽕잎 callus에서 chlorogenic acid의 함량이 약간 감소한 반면에 protocatecuic acid가 다량으로 존재하여 H. pylori의 저해 양상을 나타내는 caffeic acid, rosmarinic acid 및 chlorogenic acid 등의 phenolic compound들과의 synergy effect에 의해서 저해효과가 향상되 는 것으로 추측하였다[20]. 따라서 청목노상 뽕잎의 경우 $H$ pylori에 대한 저해제로 개발하기 위해서는 뽕잎 그 자체에서 유용물질을 분리하기 보다는 조직배양기술을 이용하여 callus 를 제조한 후 유용물질을 분리하여 산업화에 적용하는 것이 더 유리할 것으로 판단하였으며, $H$ pylori 저해효과를 가지는 callus의 배양 최적조건을 규명하여 $H$ pylori 억제물질의 생산 


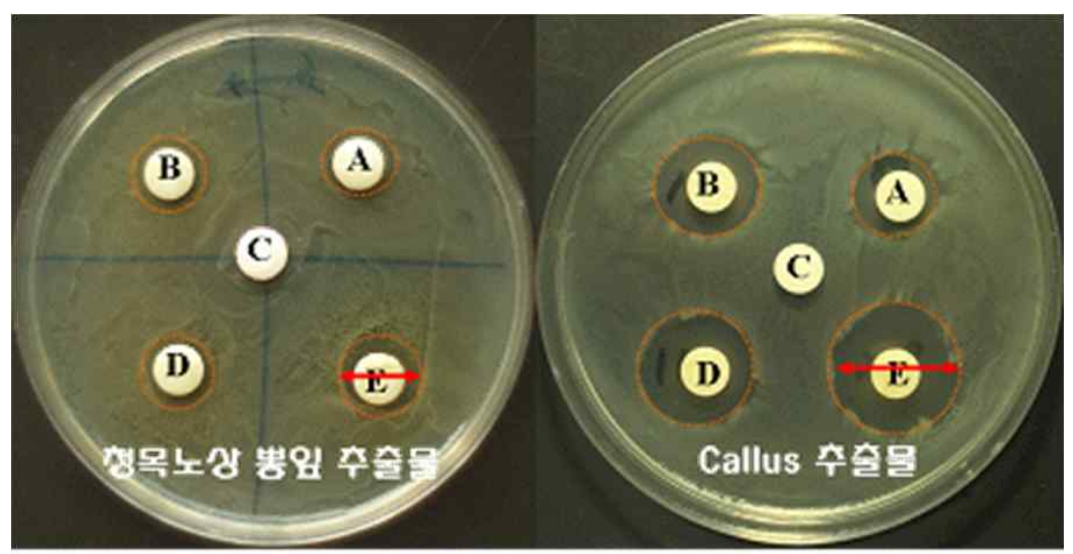

Fig. 1. Antimicrobial activity of Morus alba cv. Cheongmoknosang mulberry leaves $80 \%$ ethanol extracts and callus $80 \%$ ethanol extracts from Morus alba cv. Cheongmoknosang mulberry leaves. A: $50 \mu \mathrm{g} / \mathrm{ml}$ phenolic content, B: $100 \mu \mathrm{g} / \mathrm{ml} \mathrm{phenolic} \mathrm{content,} \mathrm{C:} 0 \mu \mathrm{g} / \mathrm{ml}$ phenolic content (control), D: $150 \mu \mathrm{g} / \mathrm{ml}$ phenolic content, E: $200 \mu \mathrm{g} / \mathrm{ml}$ phenolic content

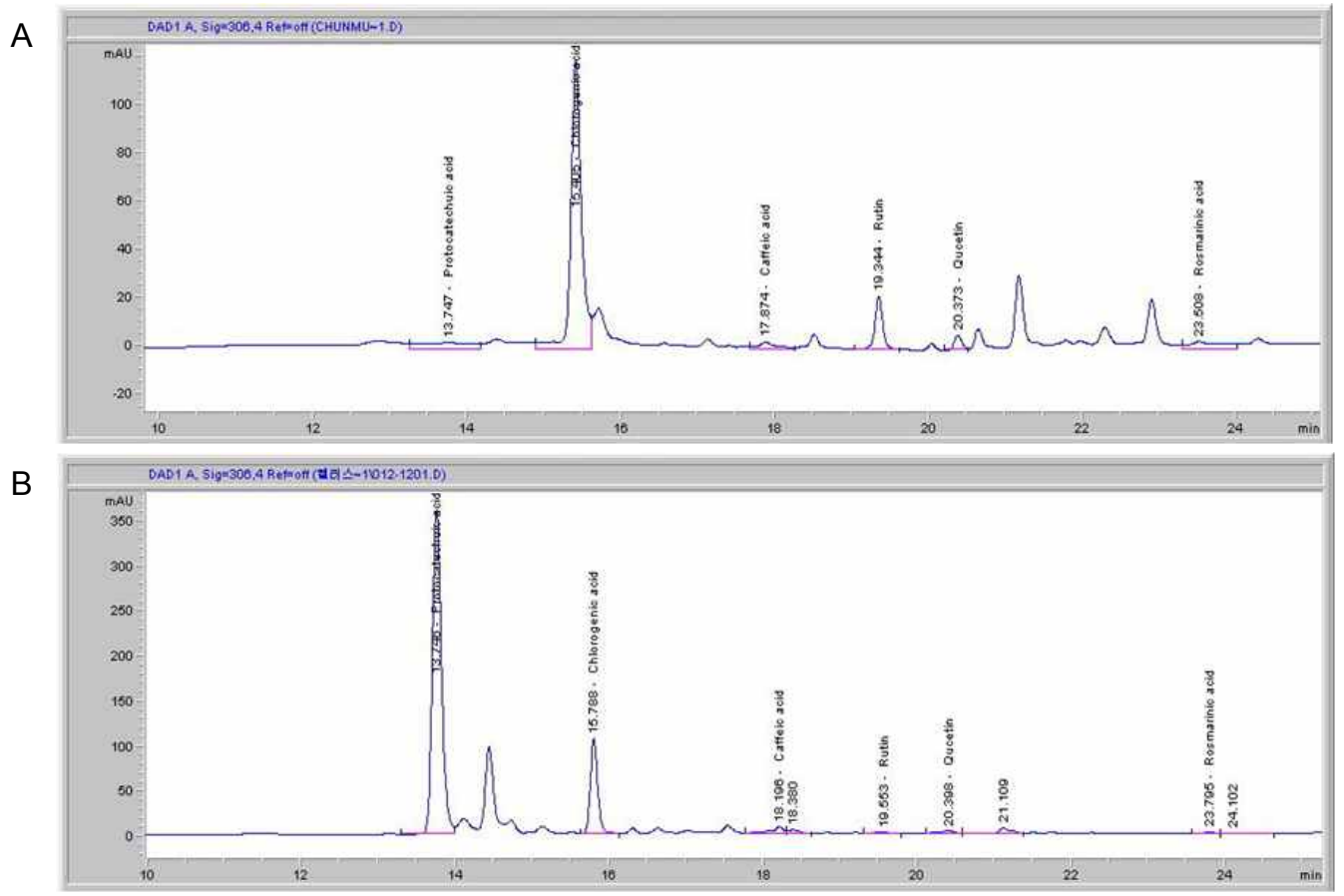

Fig. 2. HPLC profile of Morus alba cv. Cheongmoknosang mulberry leaves ethanol extracts (A) and Cheongmoknosang mulberry leaves callus ethanol extracts (B).

을 최대화 하는 것이 산업적으로 유리할 것으로 판단되었다.

\section{청목노상의 callus유도를 위한 spot 배양}

청목노상 잎 시료를 이용한 callus 유도는 Murashige와 Skoog의 MS배지를 사용하여[17], 탄소원으로 saccharose를 $30 \mathrm{~g} / 1$ 의 농도로 처리하였으며, 생장조절제로서 2,4-dichlorophenoxy acetic acid (2,4-D)를 $2 \mathrm{mg} / \mathrm{l}$ 의 농도로 처리된 배지에 시료를 치상하고 $27^{\circ} \mathrm{C}$ 에서 암배양 하였다. MS고체배 지를 이용하여 1 개월간 배양한 결과 Fig. 3 과 같이 잎으로부터
유도된 청목노상 callus $12.5 \mathrm{~g}$ 을 얻을 수 있었다.

청목노상의 callus 평판배양에 미치는 배양시간의 영향

Spot 배양에서 획득한 청목노상 callus를 증식시킬 목적으 로 캘러스(callus) 배양에 미치는 배양시간을 조사하기 위하여 생장조절제로서 2,4-dichlorophenoxy acetic acid (2,4-D)를 2 $\mathrm{mg} / \mathrm{l}$ 의 농도로 처리된 MS배지에 spot 접종하고 30 일간 배양 시킨 결과, Fig. 4 에서와 같이 20 일 배양 시 callus 생체중량이 $0.98 \pm 0.2 \mathrm{~g}$ 으로 자랐으며, 이후 배양 30 일까지 배양 callus의 


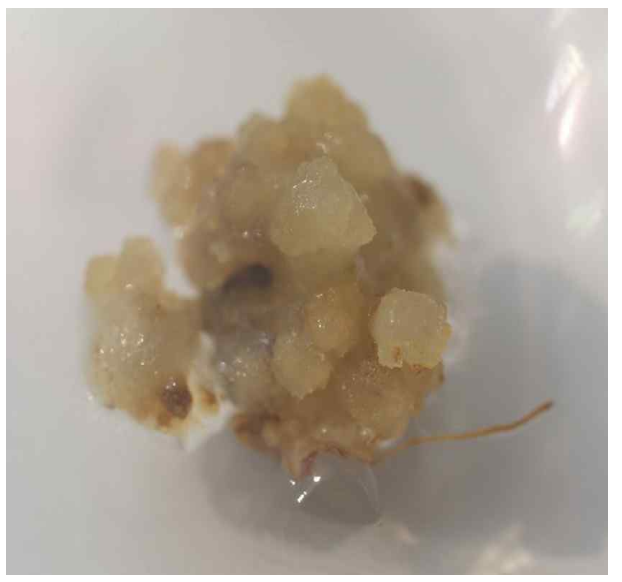

Fig. 3. Culture of Morus alba cv. Cheongmoknosang mulberry leaves callus.

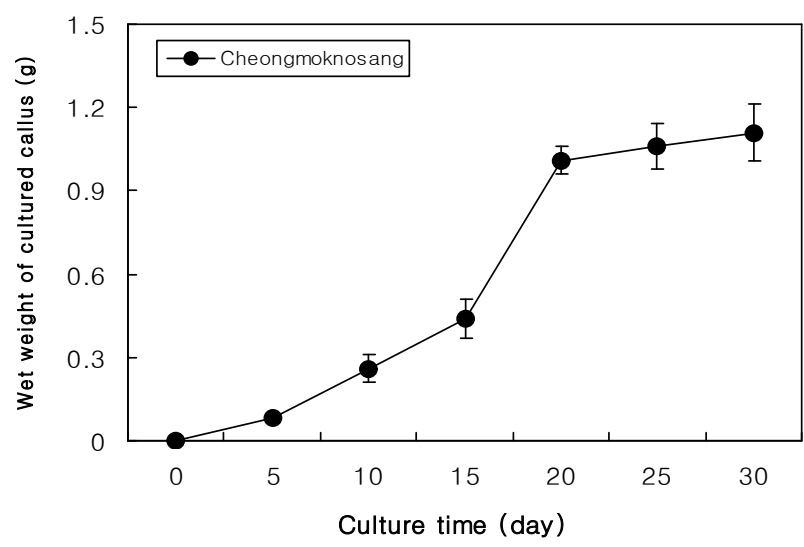

Fig. 4. Effect of culture time on callus culture from Morus alba cv. Cheongmoknosang. Each value represents the mean \pm S.D. $(n=3)$. Incubation was operated with 6-benzylaminopurine of $2 \mathrm{mg} / 1$ at $27^{\circ} \mathrm{C}$.

중량 변화는 크게 나타나지 않아 20 일 배양이 최적인 것으로 판단하였다.

\section{청목노상의 callus 평판배양에 미치는 배양온도의 영향} 청목노상의 캘러스 배양을 위한 최적 배양온도를 조사하기 위하여 생장조절제로서 2,4-dichlorophenoxy acetic acid (2,4-D)를 $2 \mathrm{mg} / 1$ 의 농도로 처리된 MS배지에 callus를 접종하 고 $25 \sim 30^{\circ} \mathrm{C}$ 까지 다양한 온도에서 20 일간 배양시킨 결과, Fig. 5 에서와 같이 $27^{\circ} \mathrm{C}$ 에서 배양하였을 때 callus 생체중이 $1.05 \pm 0.1 \mathrm{~g}$ 으로 자라 최적 배양온도는 $27^{\circ} \mathrm{C}$ 로 정하였으나, $25 \sim 30^{\circ} \mathrm{C}$ 의 배양온도 구간에서의 온도 간 차이는 거의 없는 것으로 판단되었다.

청목노상 callus 평판배양을 위한 생장조절제 단독 처리의 영향

청목노상의 callus 형성에 미치는 생장조절제의 영향을 규

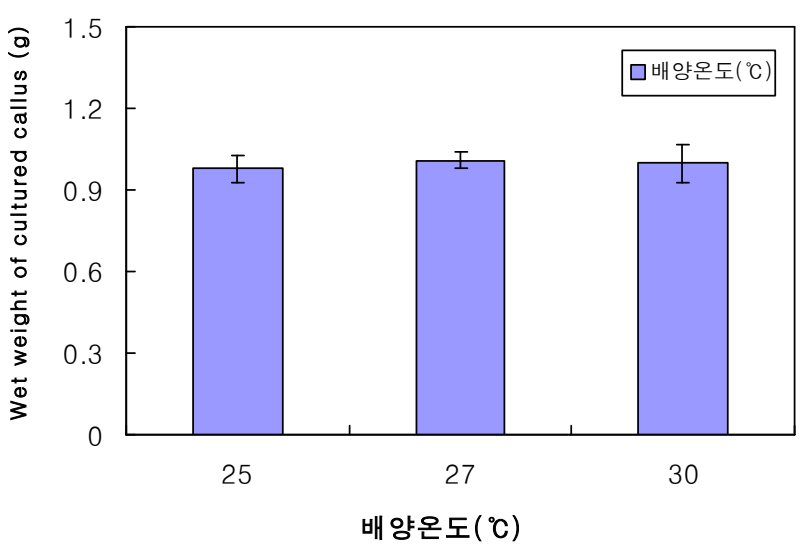

Fig. 5. Effect of culture temperature on callus culture from Morus alba cv. Cheongmoknosang. Each value represents the mean $\pm S . D$. $(n=3)$. Incubation was operated with 6-benzylaminopurine of $2 \mathrm{mg} / 1$ for 20 days.

명하기 위해 auxin으로써 2,4-D와 NAA를 사용하였고, cytokinin으로써 kinetin과 BA를 1 3 mg/l의 농도로 혼합 조제한 $\mathrm{MS}$ 배지에 치상하여 callus 형성양상을 조사한 결과, Table 1과 같이 나타났다. NAA, 2,4-D, kinetin 등은 $2 \mathrm{mg} / 1$ 의 농도로 $27^{\circ} \mathrm{C}$ 에서 20 일간 배양했을 때, $1 \mathrm{mg} / 1$ 이나 $3 \mathrm{mg} / 1$ 의 농도보다 높은 캘러스 성장률을 확인 할 수 있었고, BA의 경우 $1 \mathrm{mg} / 1$ 농도에서 상대적으로 높은 캘러스 성장률을 나타냈으며, Kinetin은 NAA, 2, 4-D, BA와 같은 생장조절제보다 캘러스 형성률이 미흡한 것으로 나타났다.

\section{청목노상 callus 평판배양을 위한 생장조절제 혼합처리의} 영향

Callus 배양을 위한 생장조절제 혼합처리의 영향을 살펴본 결과 Table 2에서와 같이 생장조절제의 혼합처리구가 Table 1 의 단독처리구 보다 캘러스 형성율이 높은 것을 확인 할 수 있었다. NAA/2,4-D/BA/KT 4 가지의 생장조절제를 전부 혼 합한 경우엔 단일생장조절제 $2,4-\mathrm{D}$ 를 $2 \mathrm{mg} / 1$ 농도로 처리 시 callus 생체중량이 $1.11 \mathrm{~g}$ 에 비하여 생장율이 높아져 callus 생 체중량이 $1.29 \mathrm{~g}$ 의 크기로 자랐으며, NAA/2,4-D/BA 등 3가 지의 생장조절제를 혼합하여 처리한 경우에는 callus 생체중 량이 $1.41 \mathrm{~g}$ 의 중량으로 성장이 우수하였다. 따라서 본 연구에 사용된 청목노상 품종의 기내 번식을 위한 direct callogenesis 의 최적 조건은 생장조절제로 NAA, 2,4-D, BA를 각각 $2 \mathrm{mg} / 1$ 씩 혼합 처리하여 $27^{\circ} \mathrm{C}$ 에서 20 일간 배양했을 때 가장 효율적 인 것으로 나타났다. 김 등[13]은 뽕나무는 목본류로 callus 생 성이 용이하지 않았고 생장도 상당히 느렸다고 보고하고 있으 며, callus 생성을 위한 생장조절제의 사용량 pattern은 본 연 구와는 다소 차이가 나는 것을 알 수 있었다. 이와 같은 결과는 뽕잎 품종별로 생장조절제의 종류에 따른 생장률의 차이 때문 으로 판단되었다. 
Table 3. Effect of plant growth regulator concentration on bioreactor for callus biomass

\begin{tabular}{lcc}
\hline Hormones & Concentration of each plant growth regulator $(\mathrm{mg} / \mathrm{l})$ & Wet weight of cultured callus $(\mathrm{g})$ \\
\hline \multirow{2}{*}{ 2,4-D+BA+NAA } & 1 & $32.06 \pm 9.7$ \\
& 2 & $49.88 \pm 6.0$ \\
\hline \multirow{2}{*}{ NAA+BA+Kinetin } & 3 & $54.85 \pm 8.9$ \\
& 1 & $55.58 \pm 8.9$ \\
& 2 & $58.45 \pm 4.3$ \\
2,4-D+BA & 3 & $55.59 \pm 2.5$ \\
\hline & 1 & $66.99 \pm 9.7^{*}$ \\
NAA+2,4-D+Kinetin & 2 & $73.01 \pm 4.3^{*}$ \\
& 3 & $72.73 \pm 6.1^{*}$ \\
\hline & 1 & $38.47 \pm 7.1$ \\
2,4-D+NAA & 2 & $35.63 \pm 7.1$ \\
& 3 & $35.63 \pm 9.7$ \\
\hline
\end{tabular}

Incubation at $27^{\circ} \mathrm{C}$ for 20 days, NAA: Naphthalene acetic acid, 2,4-D: 2,4-Dichlorophenoxy acetic acid, BA: 6-Benzylaminopurine. Each value represents the mean \pm S.D $(n=3, p<0.05)$.

Table 4. Antimicrobial activity against Helicobacter pylori of extracts from Morus alba cv. Cheongmoknosang callus

\begin{tabular}{|c|c|c|}
\hline \multirow{2}{*}{ Hormones } & \multicolumn{2}{|c|}{ Inhibitory activity } \\
\hline & Concentration of phenolic $(\mu \mathrm{g} / \mathrm{l})$ & Clear zone $(\mathrm{mm})$ \\
\hline \multirow{4}{*}{$\mathrm{NAA}+2,4$-D+Kinetin } & 50 & $10.0 \pm 0.3$ \\
\hline & 100 & $13.0 \pm 0.2$ \\
\hline & 150 & $12.0 \pm 0.5$ \\
\hline & 200 & $14.0 \pm 0.1$ \\
\hline \multirow{4}{*}{ NAA+Kinetin } & 50 & $9.0 \pm 0.2$ \\
\hline & 100 & $12.5 \pm 0.2$ \\
\hline & 150 & $13.0 \pm 0.1$ \\
\hline & 200 & $14.0 \pm 0.1$ \\
\hline \multirow{4}{*}{ 2,4-D+NAA } & 50 & $13.5 \pm 0.2$ \\
\hline & 100 & $14.0 \pm 0.1$ \\
\hline & 150 & $13.5 \pm 0.1$ \\
\hline & 200 & $14.5 \pm 0.1$ \\
\hline \multirow{4}{*}{$\mathrm{NAA}+\mathrm{BA}+$ Kinetin } & 50 & $12.0 \pm 0.1$ \\
\hline & 100 & $15.0 \pm 0.3^{*}$ \\
\hline & 150 & $13.0 \pm 0.2$ \\
\hline & 200 & $15.5 \pm 0.1^{*}$ \\
\hline \multirow{4}{*}{$2,4-\mathrm{D}+\mathrm{BA}+\mathrm{NAA}$} & 50 & $14.0 \pm 0.1$ \\
\hline & 100 & $15.0 \pm 0.2^{*}$ \\
\hline & 150 & $15.0 \pm 0.1^{*}$ \\
\hline & 200 & $15.5 \pm 0.1^{*}$ \\
\hline \multirow{4}{*}{$2,4-D+B A$} & 50 & $14.0 \pm 0.2$ \\
\hline & 100 & $15.0 \pm 0.1^{*}$ \\
\hline & 150 & $15.0 \pm 0.1^{*}$ \\
\hline & 200 & $16.0 \pm 0.2^{*}$ \\
\hline
\end{tabular}

Incubation was operated with $2 \mathrm{mg} / 1$ plant growth regulator at $27^{\circ} \mathrm{C}$, for 20 days.

NAA: Naphthalene acetic acid, 2,4-D: 2,4-Dichlorophenoxy acetic acid, BA: 6-Benzylaminopurine, Each value represents the mean \pm S.D $(n=3, p<0.05)$. 
청목노상 callus biomass를 위한 bioreactor 액체배양에 미치는 각종 호르몬의 영향

청목노상 callus의 bioreactor 액체배양을 위한 최적 생장조 절제를 찾기 위하여 여러 가지 생장조절제를 다양한 농도(1 $3 \mathrm{mg} / \mathrm{l}$ 로 제조하여 액체 배지에 첨가하고 bioreactor 액체배 양을 한 결과, Table 3과 같이 MS 액체배지를 사용하여 2,4-D 와 $\mathrm{BA}$ 를 각각 $1 \mathrm{mg} / 1$ 의 농도로 처리하여 20일간 배양하였을 때, 배양 후 침전 callus 생체중량이 $73.01 \pm 4.3 \mathrm{~g}$ 으로 최대의 생장을 나타내어 액체 대량배양을 위한 최적조건임을 알 수 있었다. 앞의 callus 배양에서는 NAA/2,4-D/BA 혼합 생장조 절제에서 가장 잘 자랐으나, bioreactor를 이용한 액체배양에 서는 2,4-D와 BA 혼합구가 가장 효율적인 것으로 나타나 액체 배양에서의 생육상태는 고체 medium에서의 생육상태와 다 소 다른 양상을 나타낸다고 판단되었다. 이것에 대한 연구는 추후 진행이 되어야 할 것으로 판단된다. 지황의 경우[18] callus 배양 시 BA와 NAA를 첨가하여 배양하였을 때 가장 높은 성장률을 보였다고 나타내었고, 따라서 청목노상 callus의 인 공대량 배양을 위한 bioreactor의 최적 조건은 MS 액체배지를 사용하여 2,4-D와 BA를 각각 $1 \mathrm{mg} / 1$ 의 농도로 처리하여 20 일 간 배양하는 것이 가장 잘 자랐다.

Bioreactor로 액체 배양된 청목노상 callus 추출물의 Helicobacter pylori 생육저해 측정

Callus 추출물의 phenolic compound 농도를 50 200 $\mu \mathrm{g} /$ $\mathrm{ml}$ 의 농도로 조절하여 $H$ pylori에 대한 저해력을 살펴본 결과 청목노상 뽕잎 추출물[8]과 비교하였을 때 callus 추출물이 뽕 잎 추출물보다 더 낮은 농도의 phenolic compound를 처리하 였을 때도 $H$ pylori 저해양상이 나타나는 것을 확인 할 수 있었 다(Fig. 1). Bioreactor로 액체 배양된 청목노상 callus 추출물의 H. pylori 생육저해 결과는 Fig. 6 과 같이 다양한 생장조절제 처리에 의해 bioreactor로 액체 배양된 callus 추출물의 $H p y$ lori 생육저해 실험에서 2,4-D와 BA를 혼합하여 배양하였을 때 H. pylori에 대하여 $200 \mu \mathrm{g} / \mathrm{ml}$ 의 phenolic 함량에서 16.0 $\mathrm{mm}$ 의 clear zone이 나타나 가장 높은 저해율을 확인할 수 있어, 억제물질의 생산을 위한 callus의 최적 액체배양조건은 2,4-D와 BA를 각각 $1 \mathrm{mg} / 1$ 의 농도로 처리하여 20 일간 배양하 는 것이 최적이었다. 이상의 실험 결과에서와 같이 최적조건 에서 배양된 callus의 추출물과 뽕잎 추출물의 $H$ pylori에 대한 항균효과를 살펴본 결과 Fig. 1에서와 같이 $200 \mu \mathrm{g} / \mathrm{ml}$ 의 phenolic 함량에서 뽕잎의 clear zone $15 \mathrm{~mm}$ 에 비하여 callus 추출 물은 $18 \mathrm{~mm}$ 정도로 항균효과가 월등히 우수하였으며, callus 배양 최적조건인 2.4-D와 $\mathrm{BA}$ 의 호르몬 혼합처리조건에서 $H$. pylori에 대한 억제효과가 최대의 clear zone으로 나타나 배양 된 callus의 생체 중량에 비례하여 $H$ pylori에 대한 항균효과가 높아지는 것을 확인할 수 있었다. 이는 청목노상 뽕잎과 뽕잎 callus 추출물에 존재하는 phenolic compound들의 profile이

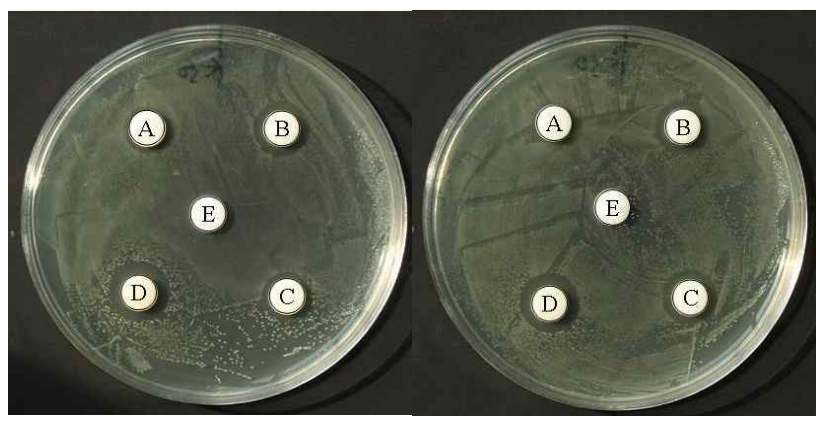

NAA+2,4-D+Kinetin

NAA+Kinetin

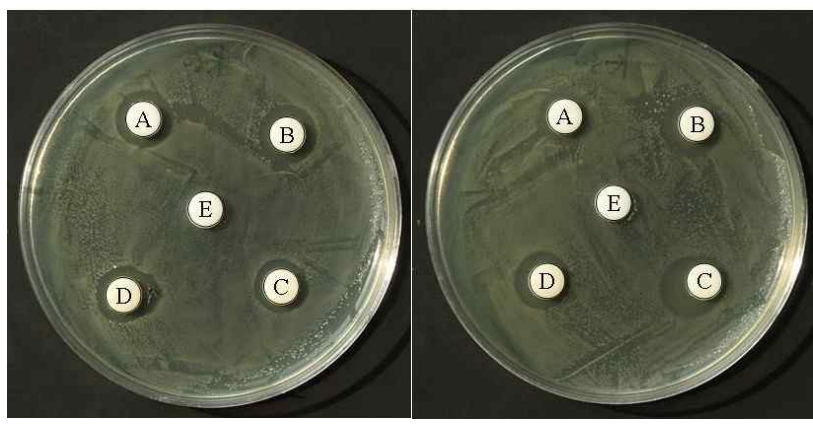

$2,4-D+N A A$

$\mathrm{NAA}+\mathrm{BA}+$ Kinetin

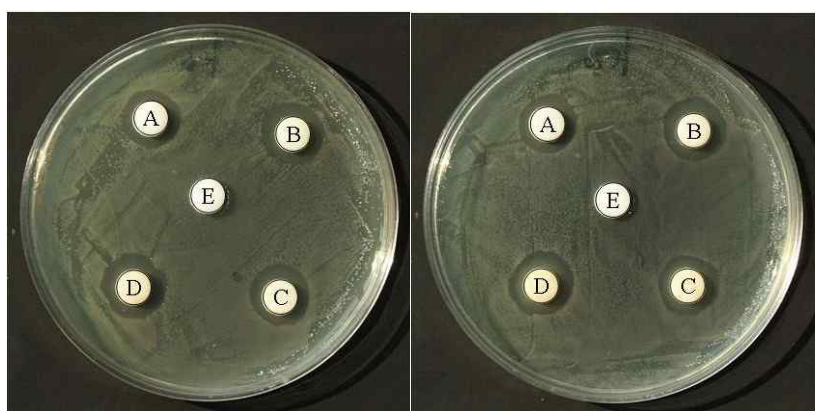

2,4-D+BA+NAA

$2,4-D+B A$

Fig. 6. Antimicrobial activity of $80 \%$ ethanol extracts from callus of Morus alba cv. Cheongmoknosang against Helicobacter pylori by disc method. A: $50 \mu \mathrm{g} / \mathrm{ml}$ phenolic content, B: $100 \mu \mathrm{g} / \mathrm{ml}$ phenolic content, C: $150 \mu \mathrm{g} / \mathrm{ml}$ phenolic content, D: $200 \mu \mathrm{g} / \mathrm{ml}$ phenolic content, E: $0 \mu \mathrm{g} / \mathrm{ml}$ phenolic content (control)

다르게 나타나며, 뽕잎추출물과 달리 뽕잎 callus에서만 확인 된 protocatecuic acid가 H. pylori에 대한 저해물질로 보고된 [9] caffeic acid, rosmarinic acid 및 chlorogenic acid 등과의 상호 작용에 의해 $H$ pylori에 대한 저해효과가 상승하는 기작 에 대해서도 향후 연구가 진행되어야 할 것으로 판단되었다.

\section{감사의 글}

이 연구는 지식경제부에서 시행한 지역산업기술개발사업 (중점기술개발사업)의 기술 개발 결과이며, 연구개발비 지원 에 감사드립니다. 


\section{References}

1. Ahn, D. 2000. Illustrated book of Korea medicinal herbs. pp. 773, Kyohak press. Seoul.

2. Asano, N., Tioka E., Kizu H. and Matsui, K. 1994. Sugars with nitrogen in the ring isolated from the Morus Bombysis. Carbohydr Res 253, 235-245.

3. Bae, K. H. 2000. Medicinal plant of Korea. pp. 73, Kyohak press. Seoul.

4. Basnet, P., Kodota, S., Terashima, S., Shimizu, M. and Namba, T. 1993. Two new 2-arylbenzofuran derivatives from hypoglycemic activity-bearing fractions of Morus insignis. Chem Pharm Bull 41, 1238-1243.

5. Chen, F., Nakashima, N., Kimura, I. and Kimura, M. 1995. Hypoglycemic activity and mechanisms of extracts from mulberry leaves (Folium mori) and cortex mori radicis in streptozotocin-induced diabetic mice. Akugaku Zasshi 115, 476-482.

6. Cho, J. H. and Byeon, J. H. 2011. Establishment of callus induction and plant regeneration system from mature seeds of Miscanthus sinensis. Korean J Plant Res 24, 628-635.

7. Cho, Y. J. and An, B. J. 2008. Anti-inflammatory effect of extracts from Cheongmoknosang (Morus alba L.) in lipopolysaccharide-stimulated raw dells. J Korean Soc Appl Biol Chem 51, 44-48.

8. Cho, Y. J., Ju, I. S., Kim, B. O., Kim, J. H., Lee, B. G., An, B. J. and Choo, J. W. 2007. The antimicrobial activity against Helicobacter pylori and antixoidant effect from the extracts of Mulberry leaves (Morus alba L.). J Korean Soc Appl Biol Chem 50, 334-343.

9. Cho, Y. J., Lee, K. H., Cha, W. S., Ju, I. S., Yoon, D. H., Ahn, B. J., Lee, S. H., Kim, M. W., Kim, J. H. and Chun, S. S. 2009. Purification and identification of inhibitory compounds from Cheongmoknosang Mulberry leaves (Morus Alba L.) on Helicobacter pylori. J Korea Soc Appl Biol Chem 52, 65-69.

10. Higasi, G. S. 2000. Appraisement of antioxidative activity from vegetables. Jpn J Food Ind 57, 56-64.
11. Jin, H. J., Lee, H. Y., Kim, D. J., Heo, M. Y. and Lee, J. H. 2005. Genotoxicity and mutagenicity of the extracts of Morus alba L. Korean J Medicinal Crop Sci 13, 217-225.

12. Kang, C. H., Han, B. S., Han, S. G., Ko, S. H. and Song, Y. J. 2011. Selection of suitable varieties of carnation (Dianthus caryophyllus L.) and optimization of culture conditions for efficient tissue culture. Korea J Plant Res 24, 121-129.

13. Kim, M. W., Roh, J. S. and Chung, K. S. 1996. Production of secondary metabolites in suspension culture of Morus alba L. Current Biochem Eng II, 73-78.

14. Kimura, M., Chen, F., Nakashima, N., Kimura, I., Asano, N. and Koya, S. 1995. Antihyperglycemic effects of N-containing sugars derived from Mulberry leaves in STZ-induced diabetic mice. J Trad Med 12, 214-220.

15. Koo, W. R., Cho, J. H., Park, C. G., Ahn, Y. S. and Park, C. B. 2011. Effect of plant growth regulators on in vitro cultured Atractylodes hybrid 'Dacchul' (A. macrocephala x A. japonica). Korean J Plant Res 24, 591-598.

16. Lee, J. S., Choi, M. H. and Jung, S. H. 1995. Blood glucose lowering effects of Mori Folium Yakhak Hoeji 39, 367-372.

17. Murashige, T. and Skoog, T. 1962. A revised medium for rapid growth and bioassays with tobacco tissue cultures. Physiol Plant 15, 473-492.

18. Park, C. H., Seong, N. S., Paek, K. Y. and Lee, C. H. 1998. Micropropagation through Callus Culture in Chinese Foxglove (Rehmannia glutinos). Korean J Plant Tissue Culture 25, 171-175.

19. Romero, A. I., Lamuela, R. M., Andres, C. and Torre, M. C. 2001. Method for the quntitative extraction of resveratrol and piceid isomers in grape berry skins. J Agric Food Chem 49, 210-215.

20. Yoon, D. H., Cha, W. S., Lee, S. H., Ahn, B. J., Kim, J. H., Chun, S. S., Bae, J. H. and Cho, Y. J. 2010. Purification of identification of inhibitory compounds on Helicobacter pylori from Cheongmoknosang callus for biomass. J Life Sci 20, 374-380. 
초록 : 청목노상(Morus alba cv. Cheongmoknosang) callus의 배양조건에 따른 Helicobacter pylori 억제물질의 생산

조영제 ${ }^{1} *$ 차원섭 ${ }^{1} \cdot$ 강선애 ${ }^{2} \cdot$ 안봉전 $^{3} \cdot$ 안동현 $^{4} \cdot$ 김명욱 $\cdot$ 채정우 ${ }^{6}$

( ${ }^{1}$ 경북대학교 식품공학부/식품생물산업연구소, ${ }^{2}$ 경북대학교 응용생명과학부, ${ }^{3}$ 대구한의대학교 화장품약리 학과, ${ }^{4}$ 부경대학교 식품공학과/식품연구소, ${ }^{5}$ 경북해양바이오산업연구원, ${ }^{6}$ 경기도산림환경연구소)

Helicobacter pylori 억제효과가 우수한 청목노상의 캘러스 배양을 위한 최적조건은 MS 고체배지에서 $27^{\circ} \mathrm{C}$ 에서 20 일간 배양하였을 때 $6.4 \mathrm{~mm}$ 의 크기로 가장 크게 자랐으며, 청목노상의 callus 형성에 미치는 생장조절제로는 NAA, 2,4-D, BA 및 kinetin 등을 $2 \mathrm{mg} / 1$ 의 농도로 첨가하여 $27^{\circ} \mathrm{C}$ 에서 20 일간 배양했을 때 높은 캘러스 성장률을 확인 할 수 있었고, 생장조절제의 혼합처리구가 단독처리구 보다 캘러스 형성율이 높은 것을 확인 할 수 있다. 따라서 본 연구에 사용된 청목노상 품종의 평판기내 배양을 위한 direct callogenesis의 최적 조건은 생장호르몬으 로 2,4-D/NAA를 $2 \mathrm{mg} / 1$ 의 농도로 혼합 처리하여 $27^{\circ} \mathrm{C}$ 에서 20 일간 배양이 최적조건이었다. 청목노상 callus로부 터 Helicobacter pylori 억제물질의 대량생산을 위한 방법인 biomass를 위한 bioreactor배양은 MS 액체배지에 호르 몬으로 2,4-D와 BA를 각각 $1 \mathrm{mg} / 1$ 의 농도로 처리하여 20 일간 배양하였을 때가 최적조건이었다. 최적조건에서 배양한 callus 추출물의 Helicobacter pylori 에 대한 억제효과는 $16 \mathrm{~mm}$ 의 clear zone으로 가장 높은 저해율을 확인 할 수 있었다. 